Prepared for the U.S. Department of Energy

Under Contract DE-AC05-76RL01830

\title{
T Farm Interim Surface Barrier Vadose Zone Monitoring FY08 Fourth-Quarter Status Report
}

Z. F. Zhang C. E. Strickland

September 2008 


\title{
DISCLAIMER
}

This report was prepared as an account of work sponsored by an agency of the United States Government. Neither the United States Government nor any agency thereof, nor Battelle Memorial Institute, nor any of their employees, makes any warranty, express or implied, or assumes any legal liability or responsibility for the accuracy, completeness, or usefulness of any information, apparatus, product, or process disclosed, or represents that its use would not infringe privately owned rights. Reference herein to any specific commercial product, process, or service by trade name, trademark, manufacturer, or otherwise does not necessarily constitute or imply its endorsement, recommendation, or favoring by the United States Government or any agency thereof, or Battelle Memorial Institute. The views and opinions of authors expressed herein do not necessarily state or reflect those of the United States Government or any agency thereof.

\author{
PACIFIC NORTHWEST NATIONAL LABORATORY \\ operated by \\ BATTELLE \\ for the \\ UNITED STATES DEPARTMENT OF ENERGY \\ under Contract DE-AC05-76RL01830
}

Printed in the United States of America
Available to DOE and DOE contractors from the Office of Scientific and Technical Information,
P.O. Box 62, Oak Ridge, TN 37831-0062;
ph: (865) 576-8401
fax: $(865)$ 576-5728
email: reports@adonis.osti.gov

\begin{abstract}
Available to the public from the National Technical Information Service, U.S. Department of Commerce, 5285 Port Royal Rd., Springfield, VA 22161 ph: (800) 553-6847 fax: $(703) 605-6900$ email: orders@ntis.fedworld.gov online ordering: http://www.ntis.gov/ordering.htm
\end{abstract}

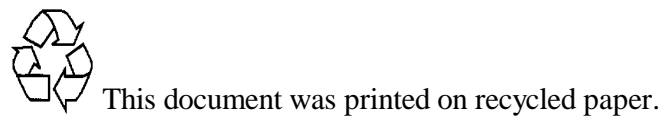




\title{
T Farm Interim Surface Barrier Vadose Zone Monitoring FY08 Fourth-Quarter Status Report
}

\author{
Z. F. Zhang C. E. Strickland
}

September 2008

Prepared for

the U.S. Department of Energy

under Contract DE-AC05-76RL01830

Pacific Northwest National Laboratory

Richland, Washington 99352 

PNNL-17914

\section{Executive Summary}

This report briefly summarizes the system status and monitoring results of Nests A, B, C and D and the Meteorological Station in the T Tank Farm from July to September, 2008. All the sensors except the two drain gauges were functional. 



\section{Acronyms and Abbreviations}

$\begin{array}{ll}\text { CP } & \text { Capacitance Probe } \\ \text { FY } & \text { Fiscal Year } \\ \text { HDU } & \text { Heat-Dissipation Unit } \\ \text { HMS } & \text { Hanford Meteorological Station } \\ \text { NP } & \text { Neutron Probe } \\ \text { PNNL } & \text { Pacific Northwest National Laboratory }\end{array}$




\section{Contents}

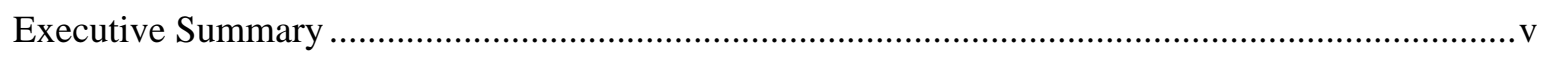

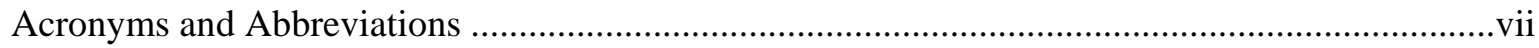

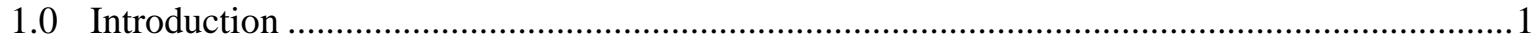

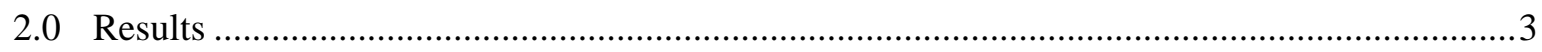

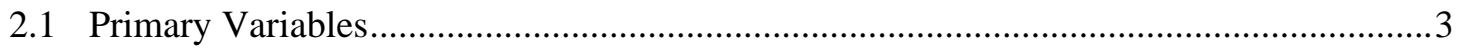

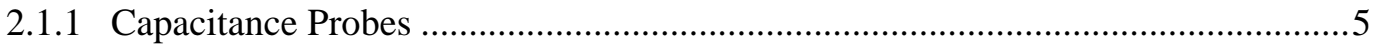

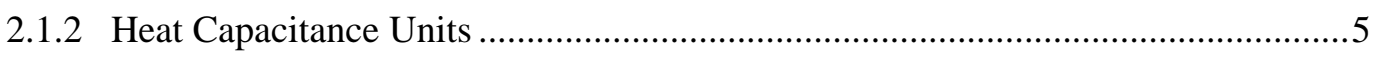

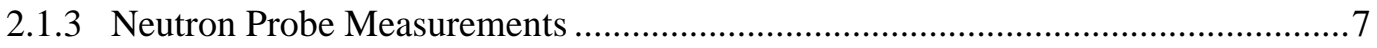

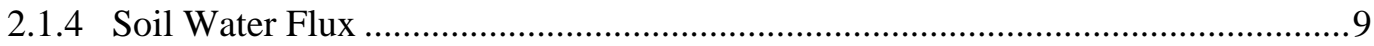

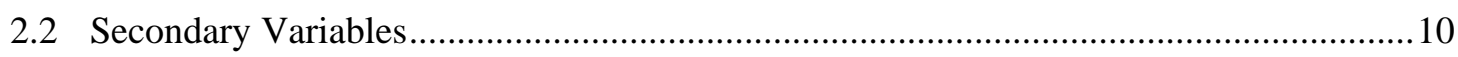

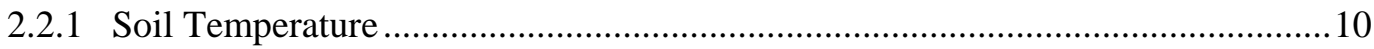

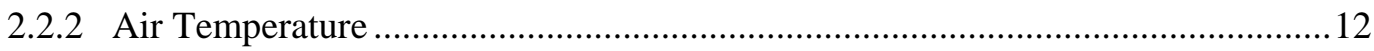

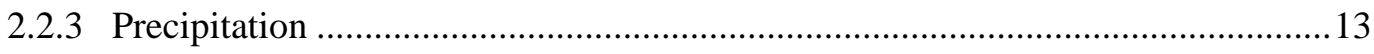

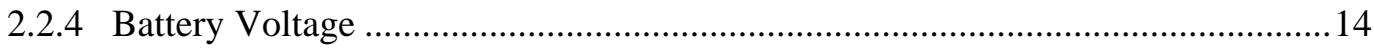




\section{Figures}

Figure 1. Daily average soil water content at five depths measured using the capacitance probes....4

Figure 2. Daily average soil water pressure at different depths measured using the heat dissipation units.

Figure 3. Normalized neutron counts at different depths measured using neutron probes (The logging on 4/9/2008 for Nest B was not considered because of numerous anomalous data).....8

Figure 4. Daily average soil temperature at different depths measured using the heat dissipation

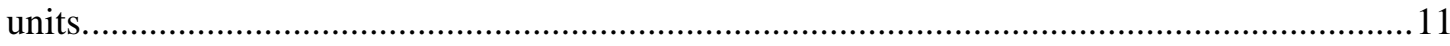

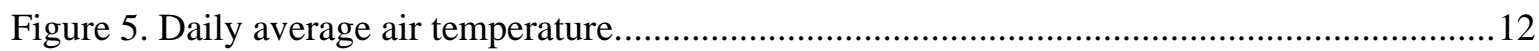

Figure 6. FY-to-date Cumulative precipitation at the T Farm and the HMS.................................13

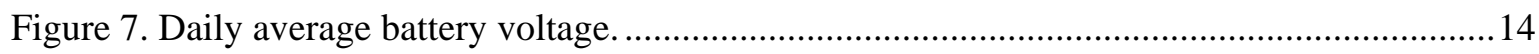




\section{Tables}

Table 1. Dynamics of soil-water content $(\theta)$ using the capacitance probes and sensor performance

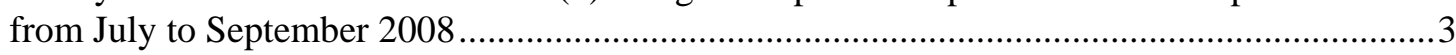

Table 2. Dynamics of soil-water pressure head $(\psi)$ from the heat dissipation units and sensor

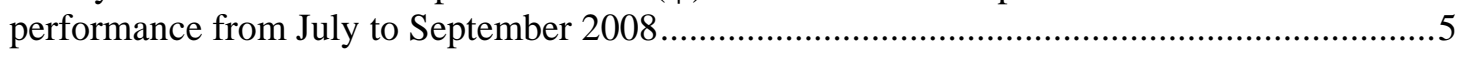

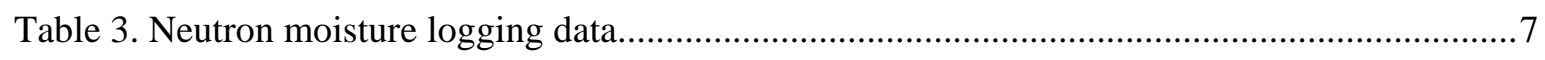

Table 4. Corrections Made to the Neutron moisture logging data ................................................

Table 5. Soil temperature $(\mathrm{T})$ variation using the heat dissipation units from July to September

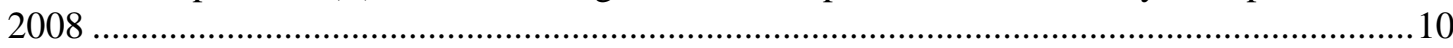




\subsection{Introduction}

This report briefly summarizes the system status and monitoring results of Nests A, B, C and D and the Meteorological Station in the T Tank Farm from July to September, 2008. For the reason of comparison, the data from October 2007 to June 2008 are also shown in the figures.

The layout of the instrument Nests and a detailed analysis of the FY07 data were summarized in the FY07 annual report (PNNL-17306, Zhang et al. 2008). Nests C and D reside under the surface barrier, Nest B near the edge of the barrier, and Nest A outside the barrier. For detailed description of the design of the monitoring system, please refer to the "T Tank Farm Interim Surface Barrier Demonstration - Vadose Zone Monitoring Plan" (PNNL-16538, Zhang et al. 2007).

The primary variables monitored include

- soil-water content measurements by the capacitance probes (CPs),

- normalized neutron counts (as a reflection of soil water content) by a neutron probe (NP)

- soil-water pressure measurements by the heat dissipation units (HDUs),

- soil-water flux measurements by the drain gauges

The secondary variables monitored include

- soil temperature measured by HDUs

- air temperature and precipitation from the T Farm Meteorological Station

- temperature within the datalogger enclosures

- battery voltages

To check the system's functionality, measured air temperature, temperature within the datalogger enclosures, and precipitation were compared with those from the Hanford Meteorological Station (HMS). 



\subsection{Results}

This section summarizes the monitoring results of both the primary and secondary variables.

\subsection{Primary Variables}

The primary variables include soil moisture content from the capacitance probes, neutron probe measurements, soil water pressure head from HDUs, and soil water flux measurements by the drain gauges.

Table 1. Dynamics of soil-water content $(\theta)$ using the capacitance probes and sensor performance from July to September 2008

\begin{tabular}{|c|c|c|c|c|}
\hline Nest & Depth (m) & $\theta$ Dynamics & Sensor Functionality & $\begin{array}{l}\text { Performance within the } \\
\text { Indicated Range? }\end{array}$ \\
\hline \multirow{5}{*}{$\mathrm{A}^{\dagger}$} & 0.6 & Stable & \multirow{5}{*}{$\begin{array}{l}\text { Functional but results } \\
\text { are suspicious }\end{array}$} & \multirow{5}{*}{ Yes } \\
\hline & 0.9 & Stable & & \\
\hline & 1.3 & Stable & & \\
\hline & 1.8 & Stable & & \\
\hline & 2.3 & Stable & & \\
\hline \multirow{5}{*}{ B } & 0.6 & Stable & Normal & Yes \\
\hline & 0.9 & Stable & Normal & Yes \\
\hline & 1.3 & Stable & Normal & Yes \\
\hline & 1.8 & Stable & Normal & Yes \\
\hline & 2.3 & Stable & Normal & Yes \\
\hline \multirow{5}{*}{$\mathrm{C}^{+\mathrm{t}}$} & 0.6 & Stable & Normal & Yes \\
\hline & 0.9 & Stable & Normal & Yes \\
\hline & 1.3 & Stable & Normal & Yes \\
\hline & 1.8 & Stable & Normal & Yes \\
\hline & 2.3 & Stable & Normal & Yes \\
\hline \multirow{5}{*}{$\mathrm{D}^{+t}$} & 0.6 & Stable & Normal & Yes \\
\hline & 0.9 & Stable & Normal after late August & Yes after late August \\
\hline & 1.3 & Stable & Normal & Yes \\
\hline & 1.8 & Stable & Normal & Yes \\
\hline & 2.3 & Stable & Normal & Yes \\
\hline
\end{tabular}

${ }^{\dagger}$ From January 31 to August 7, 2008, this CP was not functional due to ponding water found in the access tube. A replacement in late May failed also. The most recent repair occurred on August 7, 2008.

\#The sensors in Nests C and D were hooked up for logging on May 3, 2008. 

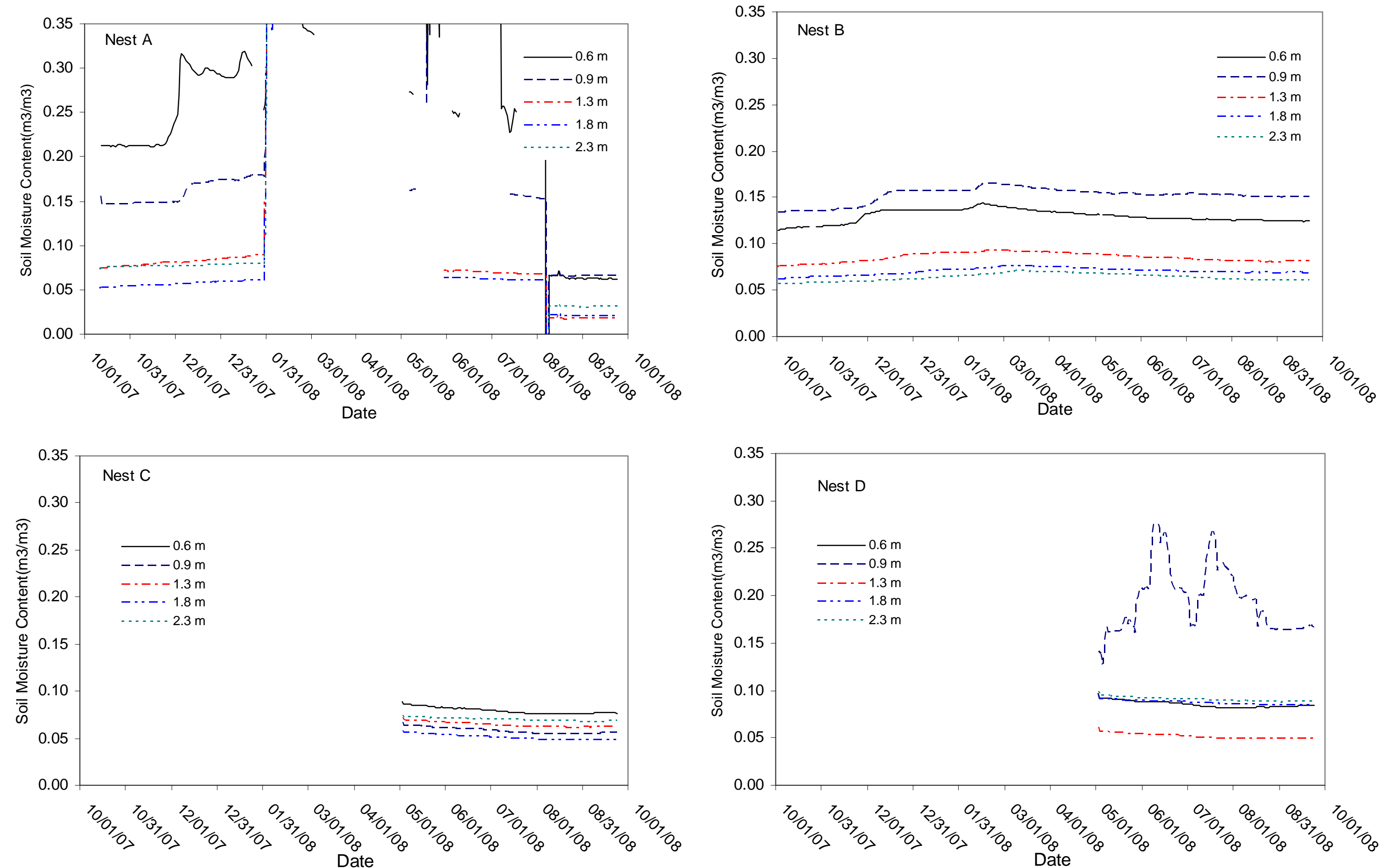

Figure 1. Daily average soil water content at five depths measured using the capacitance probes. 


\subsubsection{Capacitance Probes}

Soil water condition changes and CP-sensor performance from July to September, 2008, are summarized in Table 1. The temporal variations of CP-measured water contents in FY08 are shown in Figure 1. During this period, the CPs in Nests B, C and D were functional. The CP in Nest A was not functional through this period. Repairs the March and May were not successful due to the lack of appropriate tool. A third repair was conducted on August 7 by reusing the sensors from the CPs that might have been damaged. Hence, the data after August 7 were suspicious although the probe was functional. The Nest D CP sensor at 0.9-m depth was noisy from May to August. This might be due to bad wire connection. A repairing in August removed the noise.

\subsubsection{Heat Capacitance Units}

Soil water condition and HDU-sensor performance from July to September 2008 are summarized in Table 2. The temporal variations of HDU-measured water pressure heads in FY08 are shown in Figure 2. All the HDUs were functional during this period.

Table 2. Dynamics of soil-water pressure head $(\psi)$ from the heat dissipation units and sensor performance from July to September 2008

\begin{tabular}{|c|c|c|c|c|}
\hline Nest & Depth (m) & $\psi$ Dynamics & $\begin{array}{c}\text { Sensor } \\
\text { Functionality }\end{array}$ & $\begin{array}{l}\text { Performance within } \\
\text { the Indicated Range? }\end{array}$ \\
\hline \multirow{4}{*}{ A } & 1 & Decreasing & Normal & Yes \\
\hline & 2 & Decreasing & Normal & Yes \\
\hline & 5 & Stable & Normal & Yes \\
\hline & 10 & Stable & Normal & Yes \\
\hline \multirow{4}{*}{ B } & 1 & Decreasing & Normal & Yes \\
\hline & 2 & Decreasing & Normal & Yes \\
\hline & 5 & Stable & Normal & Yes \\
\hline & 10 & Stable & Normal & Yes \\
\hline \multirow{4}{*}{$\mathrm{C}^{\dagger}$} & 1 & Decreasing & Normal & Yes \\
\hline & 2 & Decreasing & Normal & Yes \\
\hline & 5 & Decreasing & Normal & Yes \\
\hline & 10 & Increasing & Normal & Yes \\
\hline \multirow{4}{*}{$\mathrm{D}^{\dagger}$} & 1 & Decreasing & Normal & Yes \\
\hline & 2 & Decreasing & Normal & Yes \\
\hline & 5 & Decreasing & Normal & Yes \\
\hline & 10 & Increasing & Normal & Yes \\
\hline
\end{tabular}

†The sensors in Nests C and D were hooked up for logging on May 3, 2008. 

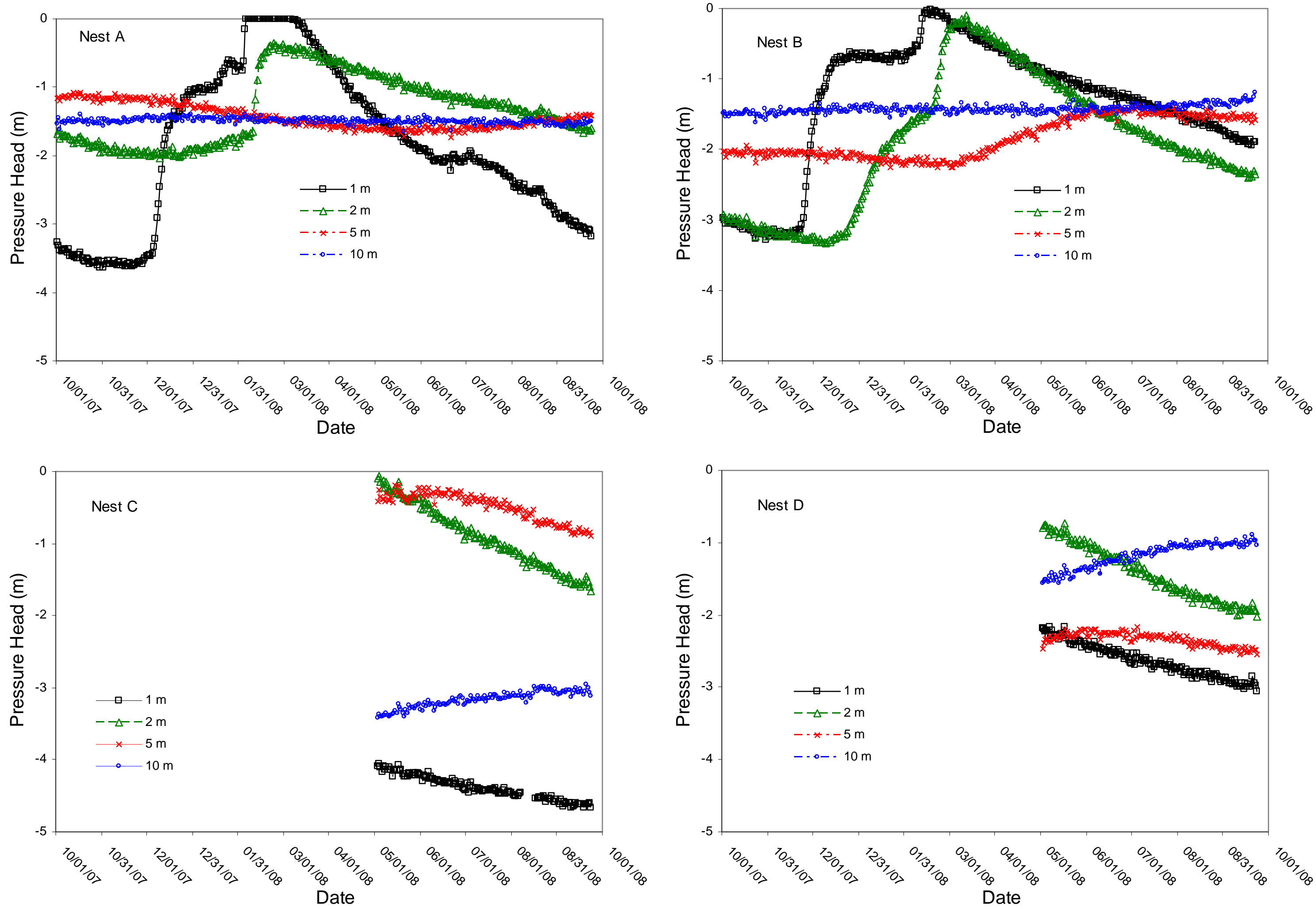

Figure 2. Daily average soil water pressure at different depths measured using the heat dissipation units. 


\subsubsection{Neutron Probe Measurements}

The neutron loggings and the NP performance in FY08 are summarized in Table 3. The profiles of normalized neutron counts are shown in Figure 3. Anomalous data were found occasionally when the observations of different dates were compared. Obvious typos (e.g., the NP counts were off by 1000) in data were corrected (Table 4). Many observations of the Nest B logging on $4 / 9 / 08$ were problematic and hence a re-logging was taken on 5/25/08.

Table 3. Neutron moisture logging data

\begin{tabular}{|c|c|c|c|c|c|}
\hline Nest & Date & $\begin{array}{c}\text { NP } \\
\text { Logged? }\end{array}$ & $\begin{array}{l}\text { Performance } \\
\text { within the } \\
\text { Indicated } \\
\text { Range? }\end{array}$ & $\begin{array}{c}\text { Any } \\
\text { Anomalous } \\
\text { data? }\end{array}$ & $\begin{array}{l}\text { Depths that anomalous data } \\
\text { were found } \\
(\mathrm{m} / \mathrm{ft})\end{array}$ \\
\hline \multirow{4}{*}{$\mathrm{A}$} & $10 / 12 / 2007$ & Yes & Yes & No & - \\
\hline & $1 / 16 / 2008$ & Yes & Yes & Yes & $0.6 / 2$ \\
\hline & $4 / 9 / 2008$ & Yes & Yes & Yes & $8.2 / 27$ \\
\hline & $7 / 30 / 2008$ & Yes & Yes & No & - \\
\hline \multirow{5}{*}{ B } & $10 / 12 / 2007$ & Yes & Yes & No & - \\
\hline & $1 / 16 / 2008$ & No & - & - & - \\
\hline & 4/9/2008 & Yes & Yes & Yes & $\begin{array}{c}3.4 / 11,8.8 / 29,9.1 / 30,10.7 / 35 \\
14.9 / 49\end{array}$ \\
\hline & $5 / 25 / 08$ & Yes & Yes & No & - \\
\hline & $7 / 30 / 2008$ & Yes & Yes & No & - \\
\hline \multirow{4}{*}{$\mathrm{C}$} & 10/12/2007 & Yes & Yes & No & - \\
\hline & $1 / 16 / 2008$ & Yes & Yes & No & - \\
\hline & $4 / 9 / 2008$ & Yes & Yes & No & - \\
\hline & $7 / 30 / 2008$ & Yes & Yes & No & - \\
\hline \multirow{4}{*}{$\mathrm{D}$} & $10 / 12 / 2007$ & Yes & Yes & No & - \\
\hline & $1 / 16 / 2008$ & Yes & Yes & Yes & $5.8 / 19,7.0 / 23$ \\
\hline & $4 / 9 / 2008$ & Yes & Yes & No & - \\
\hline & $7 / 30 / 2008$ & Yes & Yes & No & - \\
\hline
\end{tabular}

Table 4. Corrections Made to the Neutron moisture logging data

\begin{tabular}{|c|c|c|c|c|c|}
\hline Nest & Date & Depth $(\mathrm{m} / \mathrm{ft})$ & $\begin{array}{c}\text { Suspected } \\
\text { Reading }\end{array}$ & $\begin{array}{c}\text { Previous two } \\
\text { readings }\end{array}$ & $\begin{array}{c}\text { Corrected } \\
\text { Reading }\end{array}$ \\
\hline $\mathrm{A}$ & $1 / 16 / 2008$ & $0.6 / 2$ & 5907 & 3052,2813 & 2907 \\
\hline $\mathrm{A}$ & $4 / 9 / 2008$ & $8.2 / 27$ & 3318 & 2327,2382 & 2318 \\
\hline $\mathrm{D}$ & $1 / 16$ & $5.8 / 19$ & 2426 & 3534,3406 & 3426 \\
\hline $\mathrm{D}$ & $1 / 16$ & $7.0 / 23$ & 3780 & 2663,2782 & 2780 \\
\hline
\end{tabular}



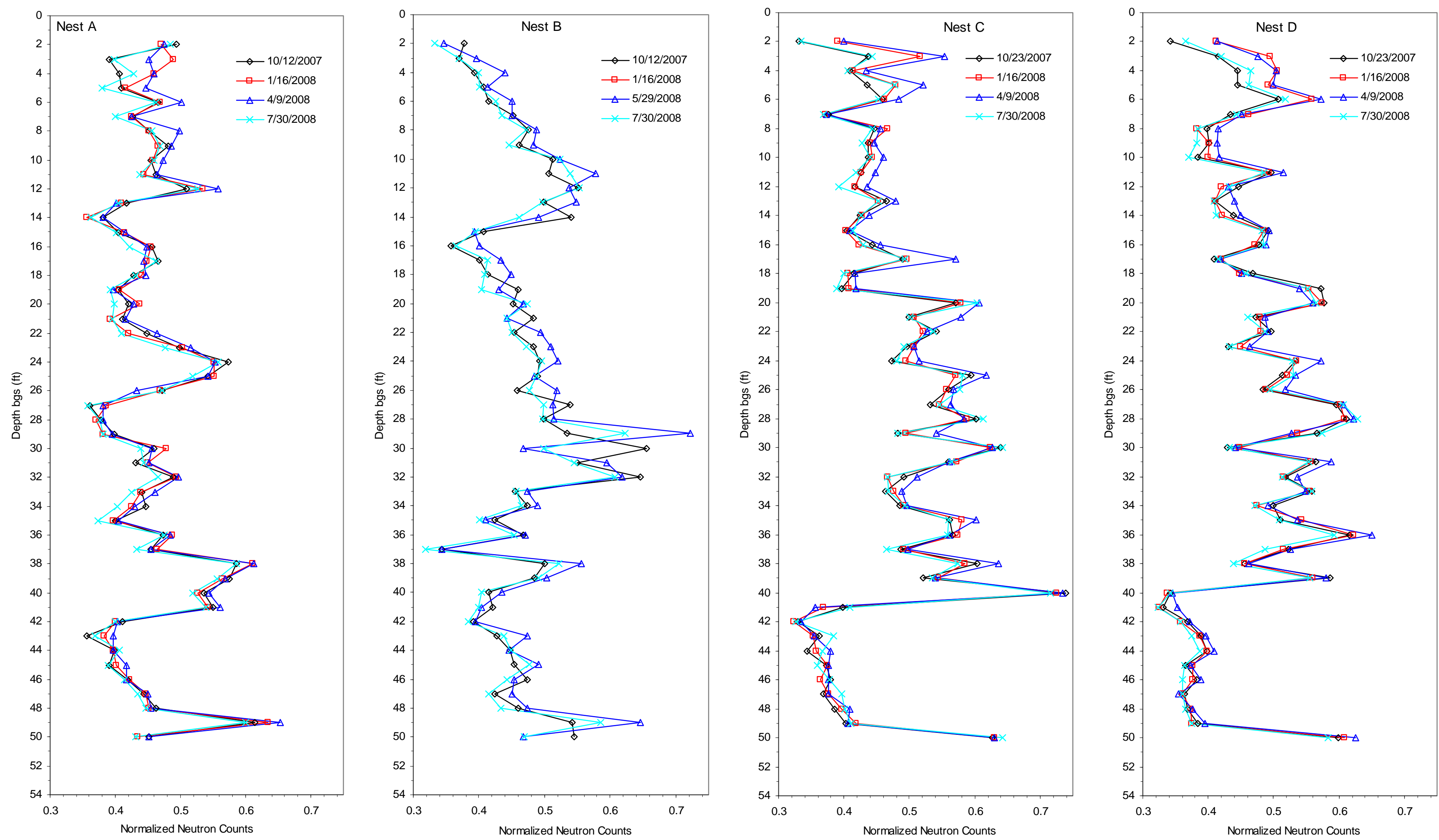

Figure 3. Normalized neutron counts at different depths measured using neutron probes (The logging on 4/9/2008 for Nest B was not considered because of numerous anomalous data). 


\subsubsection{Soil Water Flux}

Neither of the two drain gauges detected any drainage. 


\subsection{Secondary Variables}

The secondary variables include soil temperature, air temperature, precipitation, and battery voltage. These variables do not reflect any soil water condition but are used for other purposes. Soil temperature is used to correct any temperature impacts on the HDUs. The weather data are for the local climatic conditions. These data are also used to examine system functionality.

Table 5. Soil temperature (T) variation using the heat dissipation units from July to September 2008

\begin{tabular}{|c|c|c|c|c|}
\hline Nest & $\begin{array}{l}\text { Depth } \\
(\mathrm{m})\end{array}$ & T Dynamics & $\begin{array}{c}\text { Sensor } \\
\text { Functionality }\end{array}$ & $\begin{array}{l}\text { Performance within } \\
\text { the Indicated Range? }\end{array}$ \\
\hline \multirow{4}{*}{ A } & 1 & Decreasing & Normal & Yes \\
\hline & 2 & Increasing-Decreasing & Normal & Yes \\
\hline & 5 & Increasing & Normal & Yes \\
\hline & 10 & Stable & Normal & Yes \\
\hline \multirow{4}{*}{ B } & 1 & Decreasing & Normal & Yes \\
\hline & 2 & Increasing-Decreasing & Normal & Yes \\
\hline & 5 & Increasing & Normal & Yes \\
\hline & 10 & Stable & Normal & Yes \\
\hline \multirow{4}{*}{$\mathrm{C}$} & 1 & Decreasing & Normal & Yes \\
\hline & 2 & Increasing-Stable & Normal & Yes \\
\hline & 5 & Increasing & Normal & Yes \\
\hline & 10 & Stable & Normal & Yes \\
\hline \multirow{4}{*}{$\mathrm{D}$} & 1 & Decreasing & Normal & Yes \\
\hline & 2 & Increasing-Stable & Normal & Yes \\
\hline & 5 & Increasing & Normal & Yes \\
\hline & 10 & Stable & Normal & Yes \\
\hline
\end{tabular}

\subsubsection{Soil Temperature}

The HDU performance from July to September 2008 are summarized in Table 5. The soil temperature variations for all the sensors in FY08 are shown in Figure 4.

- All the HDU sensors were in normal function

- The measured soil temperature from Nests A and B were very similar to those a year ago. The curves for Nests $\mathrm{C}$ and $\mathrm{D}$ were similar to the corresponding portions in the plots for Nests A and B. 

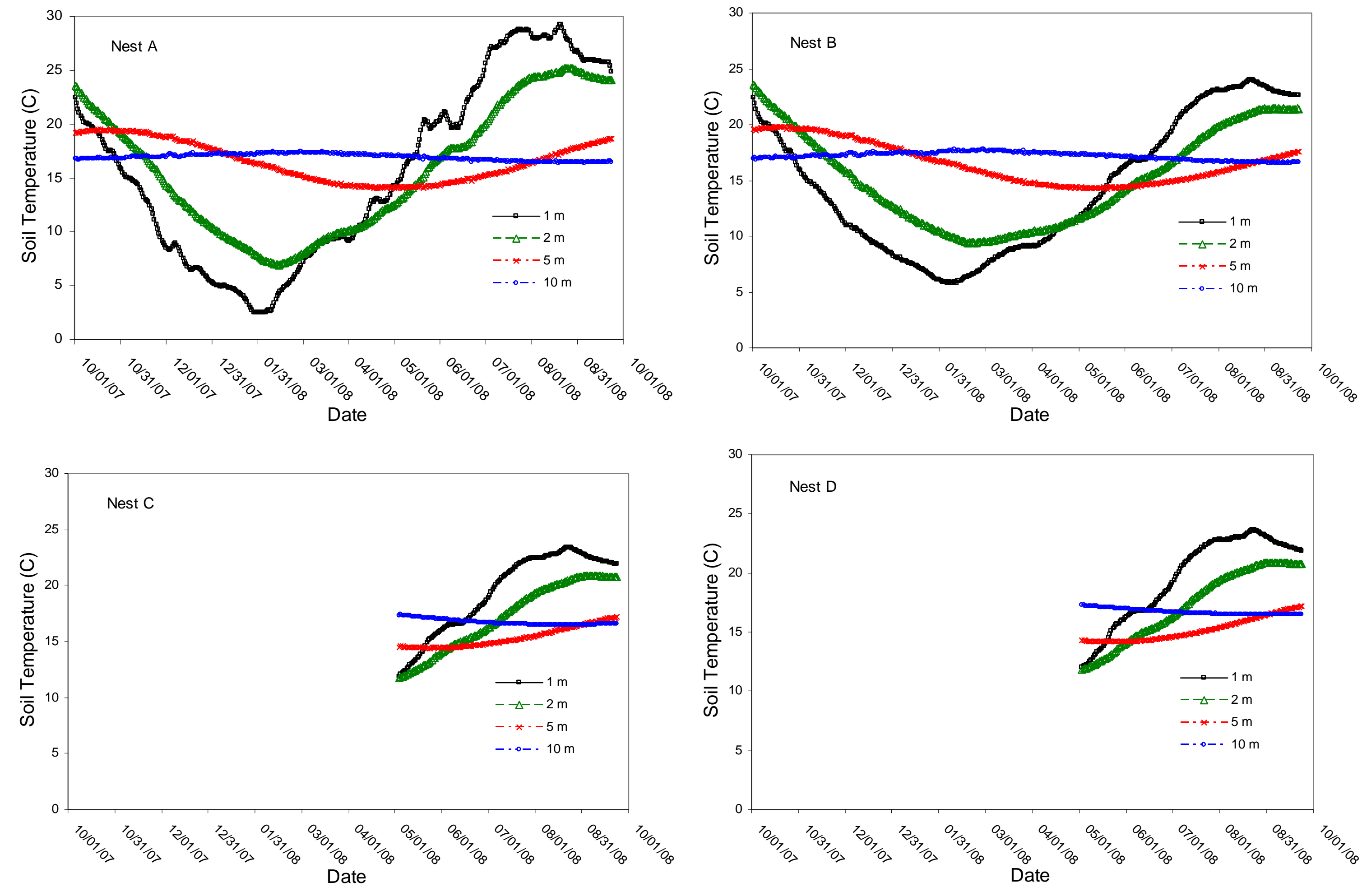

Figure 4. Daily average soil temperature at different depths measured using the heat dissipation units. 


\subsubsection{Air Temperature}

The measured daily average air temperature outside of the fence of T Farm, the reference temperature of the dataloggers in Nests A, B, C and D, and the air temperature from the Hanford Meteorological Station (HMS) in FY08 are plotted in Figure 5. They all are in good agreement.

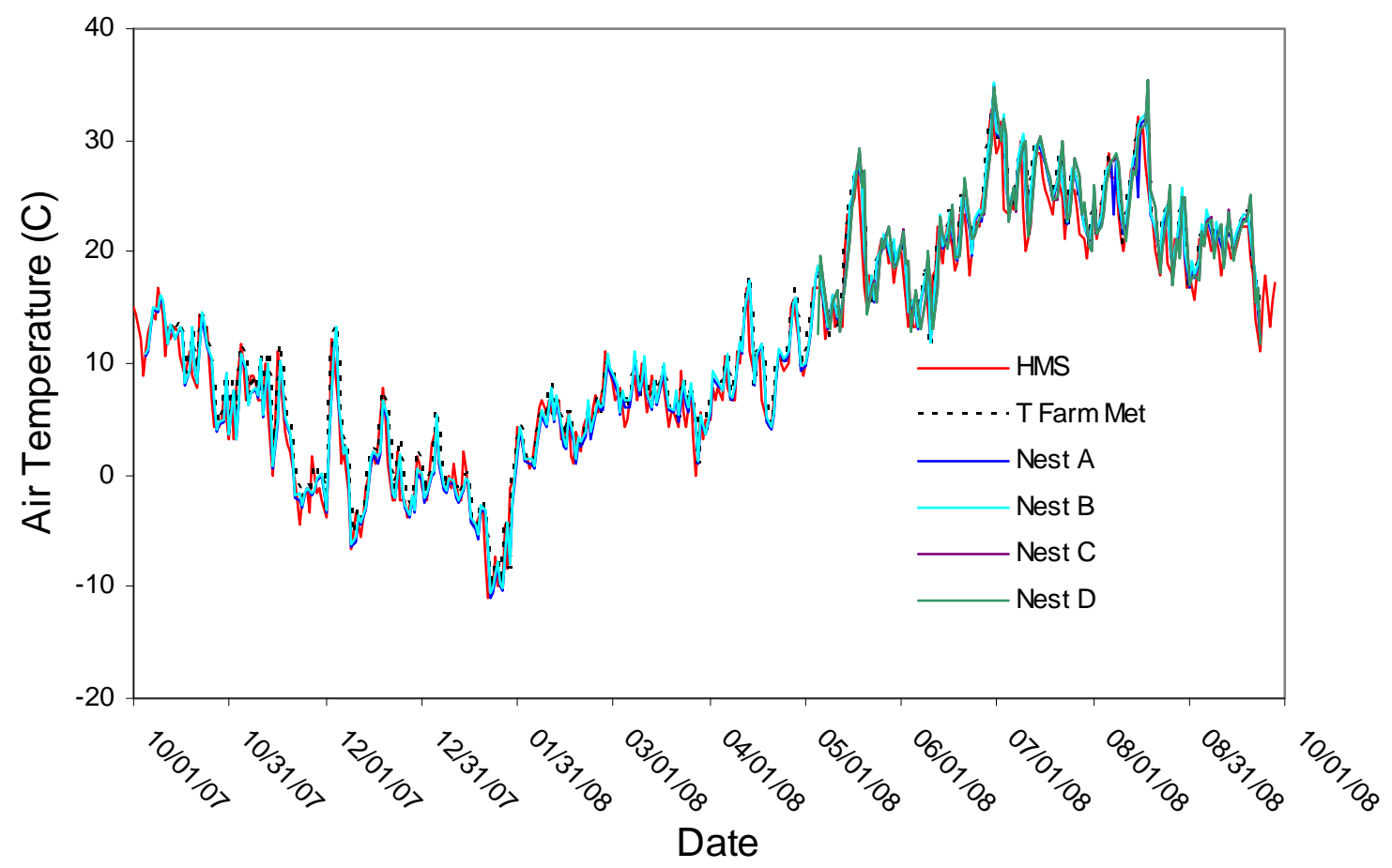

Figure 5. Daily average air temperature. 


\subsubsection{Precipitation}

The FY-to-date cumulative precipitation measured outside of the fence of T Farm and that from the HMS are plotted in Figure 6. The FY08 cumulative precipitation in the T Farm were significantly (30\%) less than the HMS measurements. There may be multiple causes to the differences. The T Farm rain gauge is not heated and hence it may underestimate snow amount. The calibration coefficient may have changed during the course of the observation. It is also possible that the actual precipitation at the T Farm was different from that at the HMS. Further investigation will be conducted.

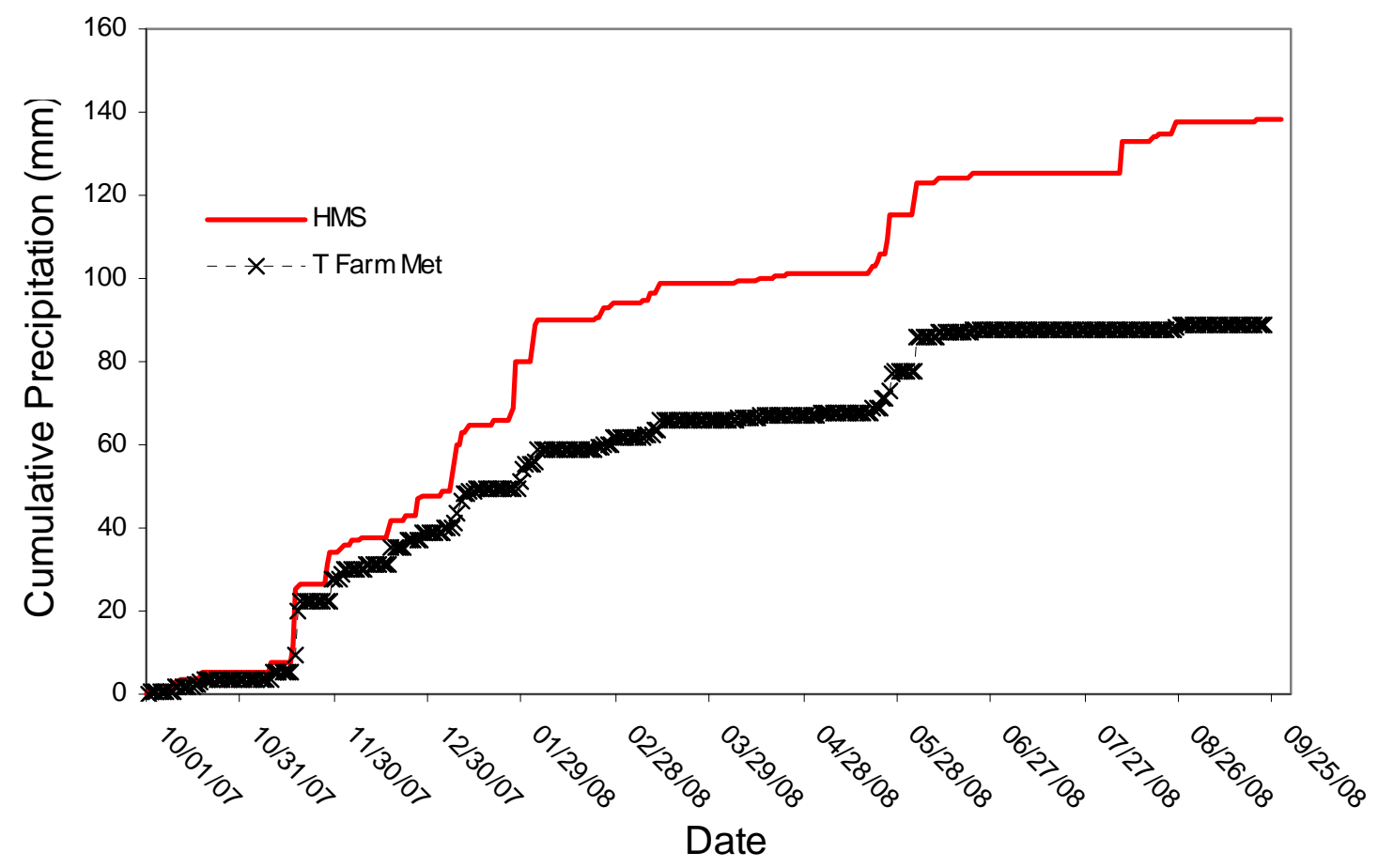

Figure 6. FY-to-date Cumulative precipitation at the T Farm and the HMS. 


\subsubsection{Battery Voltage}

A battery is used for each of the instrument nests and the meteorological station. Each battery is recharged by a connected solar panel. Battery voltage larger than $12 \mathrm{~V}$ is required to provide sufficient power to the instrument. The variations in battery voltages in Nests A, B, C and D and the T Farm Met station are plotted in Figure 7. For all three batteries, the minimum voltage was no less than $12.5 \mathrm{~V}$, which indicates sufficient power to the instruments.

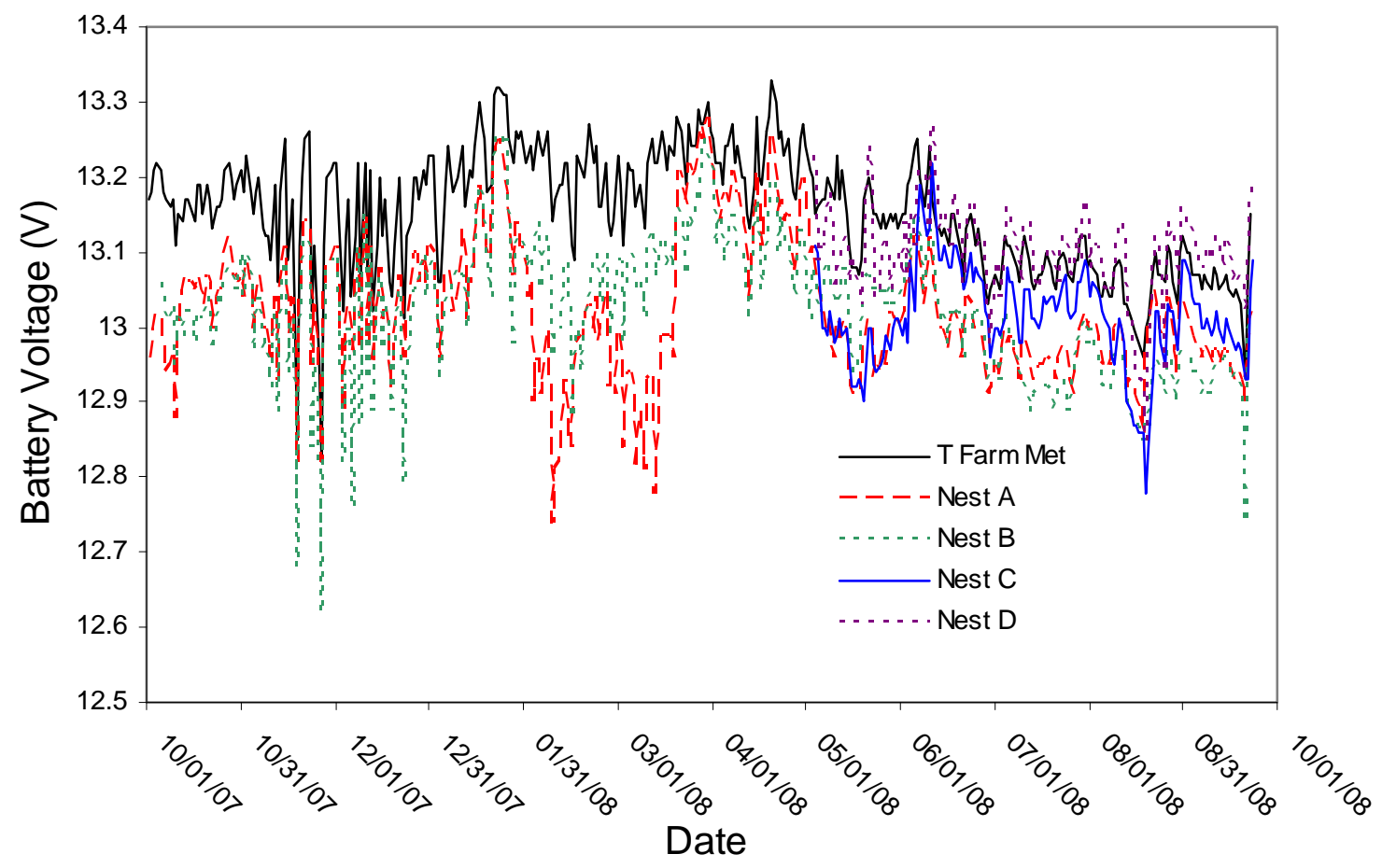

Figure 7. Daily average battery voltage.

\section{References}

Zhang ZF, JM Keller, and CE Strickland. 2007. T Tank Farm Interim Surface Barrier Demonstration Vadose Zone Monitoring Plan. PNNL-16538, Pacific Northwest National Laboratory, Richland WA.

Zhang ZF, CE Strickland, and JM Keller. 2008. T Tank Farm Interim Surface Barrier Demonstration Vadose Zone Monitoring FY07 Report. PNNL-17306, Pacific Northwest National Laboratory, Richland WA. 
PNNL 17914

\section{Distribution}

No. of

Copies

3 CH2M-HILL Hanford Group, Inc.

C.D. Wittreich

J.G. Field

D.L. Parker

(PDF)

(PDF)

(PDF)

\section{Local Distribution}

2 Pacific Northwest National Laboratory Z.F. Zhang

C.E. Strickland
No. of

Copies

Name Mailstop Name (PDF) 


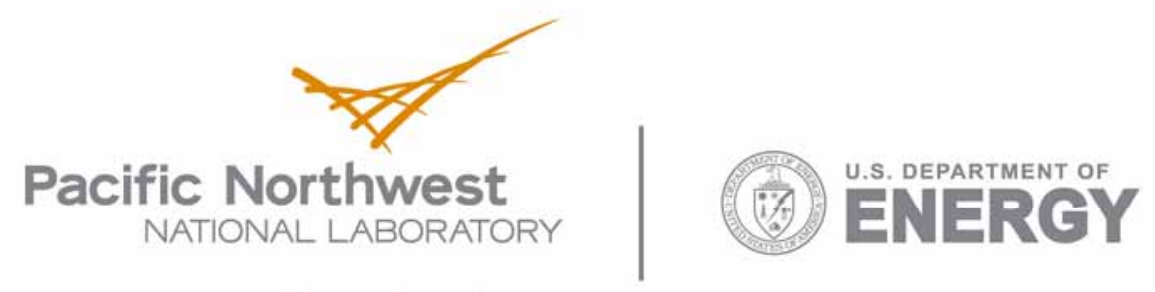

902 Battelle Boulevard

P.O. Box 999

Richland, WA 99352

1-888-375-PNNL (7665)

www.pnl.gov 